\title{
Nicolaus Friedreich and Degenerative Atrophy of the Posterior Columns of the Spinal Cord
}

\author{
F. ANDERMANN
}

SUMMARY: $A$ short outline is given of the pioneer efforts of Nicolaus Friedreich in the description of the spinocerebellar degeneration which now bears his name.

RÉSUMÉ: Un court résumé de la vie de Nicolaus Friedreich est intégré à sa description princeps de la dégénérescence spinocérébelleuse qui porte maintenant son nom.
From the Department of Neurology and Neurosurgery, McGill University and Montreal Neurological Hospital and Institute.

Reprint requests for the complete supplement on Friedreich's ataxia to: Dr. André Barbeau, Clinical Research Institute of Montreal, 110 Pine Avenue West, Montreal H2W IR7 Quebec, Canada.
Few eponyms in neurology are as closely identified with a specific condition as the name of Friedreich with the most common of the spinocerebellar degenerations which he identified and described. The last of his papers on the subject was published in 1877 .

Friedreich was born on July 31 , 1825 in Würtzburg, the son and grandson of professors of medicine at that university. He studied biology and medicine, developing an early interest in anatomy under the guidance of Kölliker. In 1948, Rudolf Virchow was appointed Professor of Pathology in Würtzburg, and young Friedreich fell and remained under his spell for the rest of his life. This was the era of cellular pathology, and clinicopathological correlation became Friedreich's main approach to the study of disease (Figure 1).

The publication of his Privat Docent thesis: "Contributions to the Study of Intracranial Tumors" was the first indication of an interest in the study of the nervous system which was to develop into the main preoccupation of his clinical life. He considered a career as a pathologist, but at the age of thirty-two accepted the directorship of the Medical Clinic and the Chair of Internal Medicine at the University of Heidelberg, where he continued to work for his remaining twenty-five years. Hard-working and productive, he wrote eight monographs and fifty-one papers, including studies on clinical cardiology; cavitating lesions of the lung; and diseases of the nose, larynx, trachea, thyroid, and thymus, the latter seemingly linked by their regional proximity. His major work "Progressive Muscular
Atrophy, or True and Pseudohypertrophy of Muscle" was published in 1872. He considered these disorders to be mainly myopathic as opposed to the neurogenic theory of the French School of the time. A hundred years later, the conflict is still with us, not quite resolved. His fame as a clinician and teacher was widespread, and the kindness and consideration with which he treated his patients, legendary. He was devoted to medical science, his patients and his family. Seemingly, he had no other interests.

The first symptoms of heart disease developed at the age of thirtyeight, during a mountain climbing excursion with Virchow. Four years before his death at the age of fiftyseven, he correctly diagnosed his aortic aneurysm. He bore the pain stoically, without complaining to his wife and colleagues and he worked until the end.

Tabes dorsalis was common in Friedreich's time, and the involvement of the posterior columns had been demonstrated microscopically; its relationship to syphilis was of course still unknown. He recognized the heterogeneity of what was then called tabes dorsalis, and correctly predicted that different disorders of the spinal cord would be identified and characterized, much as had been done in the case of Bright's disease and other conditions.

Friedreich set out to segregate and describe a specific form of spinal degeneration with distinctive clinical and pathological findings, which he had encountered in nine members of three sibships attending the University Clinic. In the detailed medical writing style of his time and place, he recorded his observations in a 


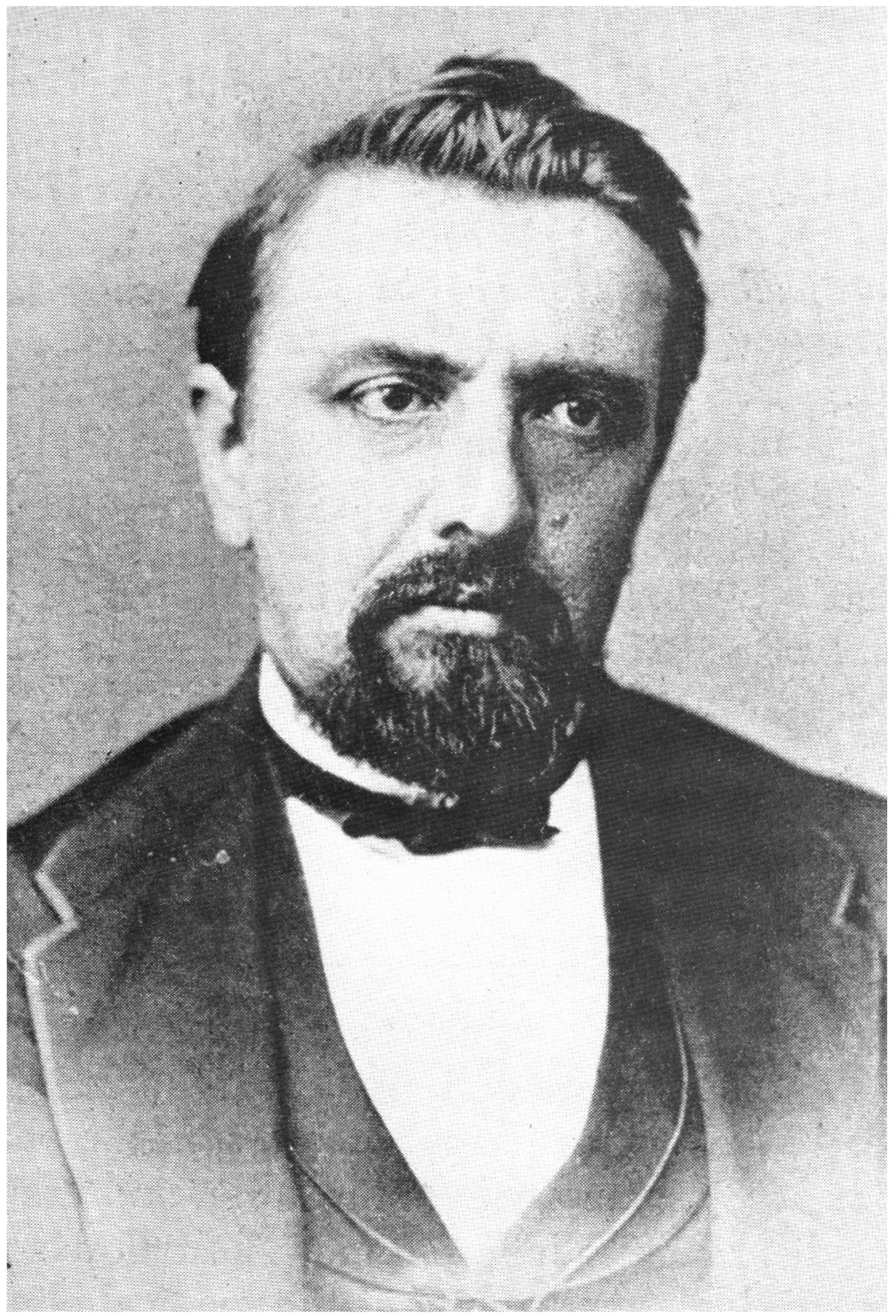

Figure I - From a portrait in the Yale Library (Phot. Lange, Heidelberg).

series of five papers between 1863 and 1877 (1863a, 1863b, 1863c, 1876, 1877). Ataxia and dysarthria were cardinal features, the latter quite distinct from the findings in tabes. He devoted much time to discussion of the sensory findings which he thought developed late and progressed slowly, and in particular attempted to distinguish the disorder of coordination derived from sensory loss, from ataxia not related to a disorder in sensory input. Power was initially normal though some proximal weakness tended to appear later. Nystagmus was not a consistent finding; Friedreich discussed its pathogenesis at length and coined the term "ataxic nystagmus", which is still used today. He stressed the absence of other ocular findings.

The bulk of Friedreich's discus- sion concerned the pathological basis of ataxia, and represented an attempt to correlate the pathological findings, with the clinical signs of his patients. He astutely implied that such signs as dysarthria and nystagmus were due to a proximal extension of the degenerative process. In his last papers he mentioned the deep tendon reflexes which were just being recognized at that time. When he tried to elicit them in his surviving patients, he found them absent. The somatic features (scoliosis, foot deformity, and heart disease) were noted and described. The pathological observations made by Friedreich and in ever greater detail by his pupil and associate Schultze have been summarized in Tyrer's (1975) excellent review. There was "degeneration of the posterior columns throughout the spinal cord, continuing to some extent into the medulla oblongata. The posterior columns appeared noticeably narrow and concave, and had a greyish translucent appearance throughout their length. The changes were most conspicuous in the lumbar regions, where Friedreich thought the process started. He also noted that similar changes might involve the lateral columns. Microscopically, he described atrophy of nerve fibers, demyelination and replacement by fine fibrillary tissue in the affected regions. He also noted degeneration of cells in Clarke's column and in the hypoglossal nuclei. The posterior spinal nerve roots were described as thin and atrophic, especially in the lumbar region and in the cauda equina", (Figure 2).

The early clinical descriptions were not immediately accepted as being of a new clinical entity; Charcot and his school considered that they represented cases of multiple sclerosis, probably because of the striking dysarthria and the nystagmus. Friedreich was quite indignant at their suggestion, wondering how his eminent French colleague could disregard the description of the pathological findings or assume that he, Friedreich, could not recognize the changes of multiple sclerosis, when he saw them. Eventually, the 
Firchoon's Artion Bd. LXX.

T'aflY.

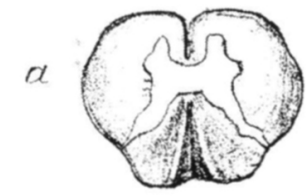

$$
\text { Fig. } 1 .
$$
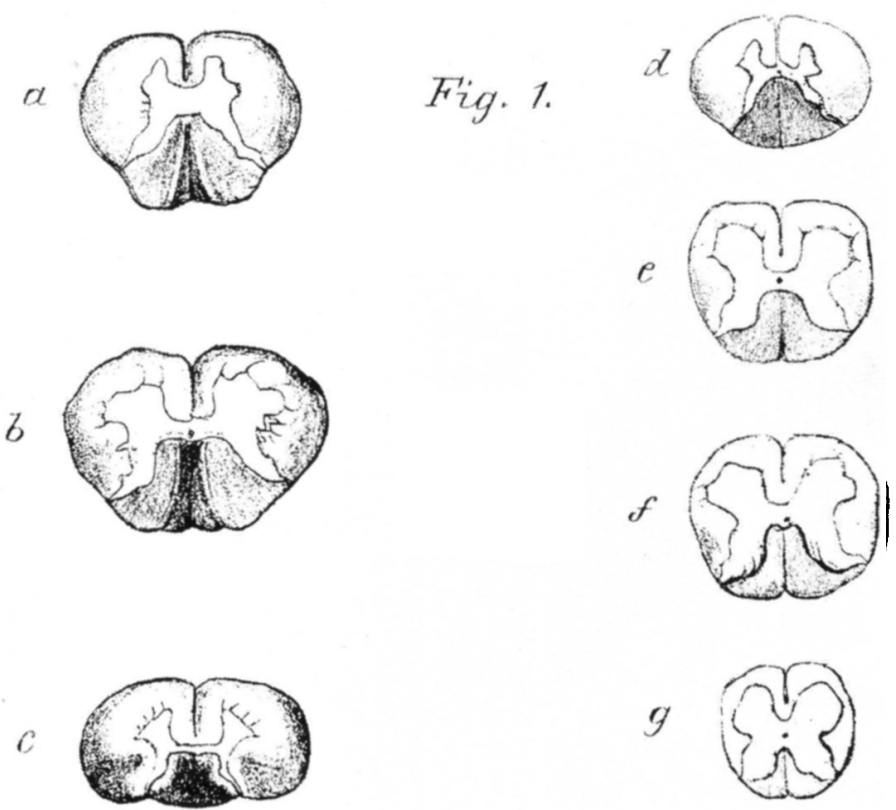

Figure 2 - Engraving of the changes in the spinal cord from the 1877 article in Virchow's Archives.

French school was convinced: Brousse of Montpellier proposed the term "maladie de Friedreich" in 1882, the year of Friedreich's death, and two years later Jean Martin Charcot described a patient from the Salpêtrière with this disorder.

As Friedreich foresaw, the spinocerebellar degenerations were described and identified both pathologically and clinically, but in disappointingly few has a biochemical etiology been discovered in the following century. In the specific form which he studied, the biochemical abnormality still eludes us, nor do we understand the significance of the occasional appearance of such features as pes cavus or scoliosis, in parents or in siblings no longer at risk. Neither do we understand the co-existence of the clinical and pathological features of the disorder with involvement of other systems, the so-called overlap or combined forms; even the reason for simultaneous occurrence of the classical clinical features with known biochemical abnormalities such as in abetalipoproteinemia, remains unexplained.

There is little doubt, however, about the clinical and pathological criteria of classical Friedreich's ataxia. They are essentially as he outlined them. As Richard Richter
(1953) wrote about his original studies, "They were pioneer achievements which laid the groundwork for all subsequent knowledge of hereditary degeneration of the spinal cord, brain stem and cerebellum. Details have been added or changed, and some of the physiologic interpretations proposed by Friedreich are no longer tenable, but the main clinical and pathological observations and ideas are sound and enduring".

\section{REFERENCES}

ANONYMOUS (1882). Obituary: Nicolaus Friedreich. Zeitschr. Klin. Med., Berlin, 5, 281-284.

FRIEDREICH, N. (1863a). Ueber degenerative atrophie der spinalen hinterstränge. Virchows Arch. Path. Anat., 26, 391-419.

FRIEDREICH, N. (1863). Ueber degenerative atrophie der spinalen hinterstränge. Virchows Arch. Path. Anat., 26, 433-459.

FREIDREICH, N. (1863c). Ueber degenerative atrophie der spinalen hinterstränge. Virchows Arch. Path. Anat., 27, 1-26.

FRIEDREICH, N. (1876). Ueber ataxia mit besonderer berücksichtigung der hereditären formen. Virchows Arch. Path. Anat., 68, 145-245.

FRIEDREICH, N. (1877). Ueber ataxia mit besonderer berücksichtigung der hereditären tormen. Virchows Arch. Path. Anat., 70, 140-152.

PAGEL, Ed. (1901). Nicolaus Friedreich Biographisches Lexicon, Berlin, Urban and Schwarzenberg, pp. 550-551.

RICHTER, R. B. (1953). Nicolaus Friedreich. In: The Founders of Neurology, Charles C. Thomas, Springfield, (Haymaker, W., ed.), 290-291.

TYRER, J. H. (1975). Friedreich's ataxia. In: Handbook of Clinical Neurology, Vol. 21, North Holland Publ. Co., Amsterdam, (Vinken, P. J., and Bruyn, G. W., eds.), 319-364.

VIRCHOW, R. (1882). Zur erinneurung an Nicolaus Friedreich. Arch. fur Path. Anat. u. Physiol, u.f. Klin. Med., 90, 215-220. 